\title{
Leveraging CSR for Sustainability: Assessing Performance Implications of Sustainability Reporting in a National Business System
}

\author{
Labrini Sideri
}

Citation: Sideri, L. Leveraging CSR for Sustainability: Assessing

Performance Implications of

Sustainability Reporting in a Nationa Business System. Sustainability 2021, 13, 5987. https://doi.org/10.3390/ su13115987

Academic Editor: Joan

R. Sanchis-Palacio

Received: 17 March 2021

Accepted: 27 April 2021

Published: 26 May 2021

Publisher's Note: MDPI stays neutral with regard to jurisdictional claims in published maps and institutional affiliations.

Copyright: (C) 2021 by the author. Licensee MDPI, Basel, Switzerland. This article is an open access article distributed under the terms and conditions of the Creative Commons Attribution (CC BY) license (https:// creativecommons.org/licenses/by/ $4.0 /)$.
Department of Economics, Faculty of Economics and Political Sciences,

National and Kapodistrian University of Athens, 15772 Athens, Greece; lab-sideri@econ.uoa.gr

\begin{abstract}
In the light of Agenda 2030 awareness of sustainability is steadily growing all over the world. Devastating phenomena like pandemics (Sustainable Development Goal 3 (SDGs-Agenda 2030)), poverty (Sustainable Development Goal 1 (SDGs-Agenda 2030)) as well as climate change (Sustainable Development Goal 13 (SDGs-Agenda 2030)) threaten humanity, calling for more sustainable solutions. Although economic growth (Sustainable Development Goal 8 (SDGs-Agenda 2030)) is one of the principal goals for a sustainable future, little research has been devoted to the interface of corporate social responsibility (CSR) and sustainability and their contribution to the financial sector, in view of sustainable banking. Even fewer are the studies concerning sustainable banking in Greece. This paper attempts a comparative overview of sustainability integration into businesses, focusing on the banking industry. The current theoretical analysis initially provides an extended review of the CSR and sustainability concepts, which is followed by a comprehensive analysis of non-financial disclosures (NFDs) and their business value, providing some evidence from Greece. The following sections refer to the performance implications and sustainability integration in the banking industry. Eventually, sustainable banking seems to enhance banking performance in a national business system. This is a very important deduction for sustainability to be both the cause and effect of corporate banking. Along with the discussion, some avenues for future research are highlighted.
\end{abstract}

Keywords: CSR commitment; ESG performance; financial performance; sustainability reporting; sustainable banking

\section{Introduction}

In 2004, Professor Wangari Maathai was awarded the Nobel Peace Prize "for her contribution to sustainable development, democracy and peace." It was the first time the Nobel was given to supporting sustainable development pursuits, recognizing the contribution of sustainable development to global growth. Since then, "sustainable development" has gradually become the dominant model for development strategies and growth policies worldwide. The reference definition of sustainable development had been given much earlier by the World Commission on Environment and Development as the "development that meets the needs of the present without compromising the ability of future generations to meet their own needs" [1].

Sustainable development, as applied to economic development, intends to improve modern societies' standards of living, without exclusive concentration on economic growth. In particular, the main objective of sustainable development strategies is to raise the quality of life for present generations to such an extent that neither the environment and resources are depleted at the expense of future generations, nor social cohesion is threatened by social inequalities and political instability. In short, sustainable development is represented by the so-called "triple bottom line development: economic-social-environmental" [2]. 
"Sustainability", a term almost synonymous with sustainable development, classifies resources as environmental, social and economic. According to the definition of Mihelcic et al. (2003) [3]: "Sustainability is defined as the design of human and industrial systems, ensuring that the human resource's use of natural resources and cycles does not lead to a diminished quality of life, due either to future economic opportunities or to adverse impacts on social conditions, human health and the environment." Similarly, Jenkins (2009) [4] argues that sustainability refers to the conservation of economy, society, and the environment, while Corporate Social Responsibility (CSR) represents the ability of business activities to maintain this sustainability.

CSR has fully entered global business strategies, via sustainability reporting, raising concerns about the performance implications of corporate sustainability, in terms of both short-term profit and numerous long-term benefits. Specifically, the performance potential of integrating sustainability initiatives into banks' business models attracted major interest of the global business community. This new and alternative type of banking, named "Sustainable Banking", claims to foster commitment to the principles of sustainable development while adding value to the whole value chain of transactions, raising financing from the investors.

Hence, three research questions arise which constitute the purpose of the current research paper:

RQ1: How does the institutional environment affect corporate sustainability performance?

RQ2: Does commitment to CSR principles financially reward companies?

RQ3: Do banking industry returns on sustainability have a positive sign?

\section{Methodology}

Content analysis research methodology was selected to address the research questions posed in the introduction. It is a systematic, demanding approach serving the purposes of both quantitative, qualitative, and mixed methods of research. Although it is widely used in many disciplines including psychology, sociology, and political science, content analysis is currently applied in sustainability research. Moreover, Weber (1985) [5] argued that "The rules of this inferential process vary with the theoretical and substantive interest of the investigator" (p. 9). Therefore, 137 academic sources have been analyzed to obtain data from both papers and books.

As already mentioned, the purpose of this paper is to highlight the impact of sustainability on business performance, including the banking sector. To that end, an extensive and thoughtful review was undertaken to retrieve the relevant literature, assessing journal articles, reports and other documents addressing the performance implications on business and banking institutions (sustainable banking). Therefore, a consistent search through several databases (e.g., Social Science Research Network, Science Direct, Strathclyde online database etc.) was conducted. Google Scholar was mostly utilized for narrowing down the articles referring to sustainable development, corporate sustainability and CSR.

The results gave a pool of journal articles, books and reports at a global, European Union (EU) and national scales. After excluding the basic definitions and the Non-Financial Reporting material, all documents were further listed in firm and bank related. Furthermore, specific key themes (environmental, social and governance (ESG) performance and financial performance) were used to assist the author for further analysis and consideration of the sustainability implications. For banking institutions, a particular group of sources has been collected regarding the concept of sustainable banking around the world, including Greece.

\section{CSR Meets Sustainability as an Integral Part of Core Business Strategy: A Critical Perspective}

Over the last few decades, there has been an emerging interest in the importance of CSR integration into the business context, as a value-adding process. Specific CSR policies are connected to strategic corporate goals, which are oriented to long-term performance 
benefits like social legitimacy [6], corporate reputation [7-9], brand image/equity [10-12], consumer loyalty/satisfaction [13-16].

Furthermore, empirical evidence has shown CSR commitment to building stronger relationships with stakeholders, through increased transparency and accountability [17-22] creating stakeholder value $[19,23]$, which is important for business viability and, therefore, financial performance (short-term performance benefits). In addition, CSR-engaged firms seem to perform better risk management [9,19,24], recruiting more talented employees [25].

Furthermore, it is often alleged that many incentives are given to firms which undertake CSR initiatives, such as tax reductions [26-28]. Therefore, these companies gain competitive advantage over others [29-31].

\section{Sustainability Reporting}

Provided that consumers' perception seems to affect their behavior towards an organization [32], the more CSR commitment the firms communicate to their internal and external stakeholders, the more legitimacy they reap. For that reason, the managers who shape the corporate CSR strategy need to considering consumers CSR perception to include it into the company's CSR policy to meet consumers' expectations [33,34]. On the other hand, stakeholders look for tangible evidence of CSR, as a sign of transparency and accountability [34]. However, in most cases, there is not enough relevant feedback between counterparties [35].

As a rule, companies express their CSR commitment through social [36] or sustainability reporting, as the best way for communicating the required information publicly [19]. Sustainability reporting is triple bottom line reporting [6], integrating information on a firm's economic, environmental and social performance into a single publication [17], also known as 'public disclosure', or 'non-financial disclosure/information' [18,37]. A sustainability report is not just an official report composed by collected numerical data. In contrast, this is supposed to initiate a dynamic process, through which CSR commitment is properly articulated, so that both internal and external stakeholders could be engaged.

For years, due to shareholder and investor pressures, managers used to ignore the possible benefits of sustainability reporting, focusing on short-term profit. After concerns about corporate responsibility towards the environment and society were voiced by other stakeholders (employees, suppliers, customers, government, non-governmental organizations (NGOs), civil society), managers have been forced to redefine their priorities. Hence, ESG disclosures have been made to bring CSR and corporate governance together as a means for companies to demonstrate that their corporate activities do not harm the environment and society, with the board of directors being increasingly engaged in an open dialogue with civil society.

Under closer scrutiny, corporate social and environmental activities have been indirectly linked to corporate business performance [23], as expected outcomes are becoming evident in the long-term. For example, good governance enhances financial performance, through transparency, accountability, and ethical leadership. Moreover, there is growing empirical evidence that ESG-prone companies financially outperform their counterparts in the long-term, due to higher reputation and better risk management $[19,38]$.

Increasing pressure for transparency and accountability by both shareholders and other stakeholders, led to the introduction of various metrics, which facilitate the measurement of ESG performance. Global Reporting Initiative (GRI) guidelines are the most frequently used sustainability reporting standards, which enable stakeholders to inspect companies' footprint to global economy, environment, and society. Large organizations and small and medium enterprises (SMEs) in various sectors and regions are also prompted to deal with this reporting process.

GRI reporting acts as the declaration of ESG commitment. In other words, sustainability/ESG reporting (sustainability and ESG reporting are used interchangeably) is the ultimate tool for companies to demonstrate their CSR commitment to all their stakeholders, informing them in detail about their performance on specific targets. In practice, however, 
the situation is more complicated, because stakeholders need to compare reports to reach a consensus. For that reason, the GRI reporting framework promotes a common standardized metrics system, which can be accessible by everyone. Thus, the units concerned can use the report as a reference point for further, horizontal, or vertical, comparisons.

Nevertheless, some researchers are skeptical about the application of GRI to sustainability reporting [35]. Particularly, in 2013, Ramanna [35] observed that GRI measures are insufficient and lacking accountability, compared to metrics used in financial reports. Accordingly, Bonsón and Bednárová (2015) [39] accuse GRI for being very complex and time-consuming, due to their numerous indices. Also, Panayiotou et al. (2009) [40] argue that, although GRI are effective CSR performance indicators, they are not applicable to all industry sectors and cannot bridge the gap between business performance and CSR strategy.

Therefore, sustainability reporting is utilized by firms as a communication tool [32] to transfer relevant information to consumers [35]. The effectiveness of sustainability reporting depends on its accountability potential and transparency to provide stakeholders with the expected negative or positive information [35]. However, materiality cannot not be expressed as a percentage, because either it exists or not. That is, some information can be disclosed, while other information is not accountable [41]. Beyond this, it is important to mention that Grewal et al. (2016) [42] found materiality to enhance a firm's value.

Addressing ESG reporting, there is considerable distance between reported activities and actual sustainability business practice [43]. Indeed, the stakeholders' perception about firms' CSR commitment, derived from CSR reports, is quite puzzling. That is, stakeholders tend to positively assess a report, if only their expectations for CSR commitment have been adequately fulfilled, no matter whether the disclosed information displays high or low commitment of the company. Furthermore, on the grounds that stakeholders look for tangible data indicating firms' CSR commitment, they prefer sustainability, rather than integrated reports, as an attempt to peruse CSR information separately $[33,41,44]$.

\subsection{Sustainability Reporting Institutionalization}

As a matter of fact, national institutional frameworks are the main determinant of sustainability performance [45]. Moreover, mandatory reporting paves the way for further integration of corporate governance and CSR, contributing to greater transparency and accountability [46]. So, the transition from a voluntary to a regulatory framework was anticipated very early [47].

Although international organizations and governments have promoted the incorporation of CSR into national legislation, only a few countries around the world have already enacted a regulatory framework for CSR reporting: India (Section 135 of India's Companies Act of 2013), Europe (Directive 2014/95/EU), UK (Companies Act 2006 (Strategic and Directors' Reports) Regulations 2013), China, Norway (Norwegian accounting legislation), Singapore (https:/ / www.sgx.com/regulation/sustainability-reporting, accessed on 6 October 2020), Malaysia (Bursa Malaysia Listing Requirements under Appendix 9C, Para 29) and South Africa (King Code of Governance (King III)) [48-52].

Eventually, voluntary sustainability reporting, because of its efficient performance implications when applied [53], became mandatory for all EU countries: Directive 2014/95/EU was immediately transposed into legislation in all member states [54]. Particularly, the Law 4403/2016 [55] introduced the obligation for all Greek large enterprises with more than 500 employees-including banks - to publish non-financial, in addition to financial, data [56].

By and large, it is argued that mandatory sustainability reporting has a major impact on market responses [42]. Like every legally regulated activity, mandatory non-financial disclosures induce credibility for stakeholders, who legitimize companies for their CSR involvement in turn [57]. As a matter of empirical evidence, equity markets tend to positively respond to the prospect of a mandatory framework, as regards firms which are 
already active in disclosing. On the contrary, they are negatively disposed to mandatory reporting, when it comes to firms with poor CSR reporting records [42].

\subsection{The Greek Case}

The first Greek National Sustainable Development Strategy (NSDS) dates to 2002, updated in 2009 by the new "Ministry of Environment, Energy and Climate Change", in the context of the national "Green Development" objective [58].

During the first four years of the millennium, Greek CSR reporting records revealed that only 10, out of 351 companies listed on the Athens Stock Exchange issued sustainability reports [59]. In addition to that, most of the disclosing companies belong to the Financial Sector [60], with $80 \%$ of them adopting GRI as their reporting framework [61]. In particular, Greek banks used to disclose only on a few social, ethical, and environmental aspects [62]. However, there is evidence that the operational sector is affecting the degree of CSR adoption. As a matter of fact, companies operating in financial services, telecommunications and petroleum industry tend to display a much higher penetration rate, compared to all other sectors [40].

Regarding GRI reporting in Greece, an EY survey (2013) [63] reveals that 78\% of Greek companies used GRI Reporting Guidelines in 2012, while 55\% of them used the G3 version. A subsequent EY survey (2015) [61] showed that 53\% of the reporting companies used G3.1 within 2013. In particular, GRI reporting in Greece reached a peak in 2010, with 54 reports having been published. Myrgioti et al. (2013) [64] believe that economic crisis affected negatively the GRI reporting rate, which declined in following years.

As far as Greece is concerned, CSR is considered as a means of gaining competitive advantage and added value to business (governance), society and environment as an outcome, to wit ESG performance. Therefore, a relevant study showed that Greek managers strived for a transparent CSR policy, executed by a single department, which discloses the available information publicly [65]. Two years after this study, Glavopoulos et al. (2014) [45] observed that during the financial crisis Greek managers reconsidered CSR as a chance to create new business opportunities, necessary to exit the current unfavorable economic situation.

Greek companies seem to attach greater importance to profile and governance criteria, at the expense of their triple-bottom performance [66]. However, although Myrgioti et al. [64] acknowledge the fragmentalization of Greek sustainability reporting in 2013, they argue that the disclosures of the GRI reporting companies use indicators which cover all CSR dimensions, equally. Subsequent research revealed that most Greek non-financial disclosures are 'greenwashing' and only a few companies have endorsed the principles of CSR development in their core strategy [67].

Generally, sustainability reporting has been weak [66], non-systematic and voluntary. Also, until recently, there was no national legal framework providing the necessary guidance [66]. Indicatively, the reporting organizations were almost always international, large private sector companies. Moreover, the most frequent kind of report was the stand-alone report-as opposed to the integrated-which usually was not prepared by a department specialized in sustainability [60]. Moreover, the Greek published reports of the previous decade lacked comprehension, uniformity, and stakeholder engagement [59].

In particular, sustainability reporting has never been institutionalized by the Greek legal system before. Moreover, political instability and recession exhausted Greek businesspeople, rendering them skeptical about the benefits of CSR. However, a targeted regulatory framework could considerably affect Greek CSR mentality [47].

Indeed, since the implementation of the European Directive in Greece (6 December 2016), Greek managers have seriously considered that the consequences of financial crisis to their companies' performance may be reversible via the incorporation of CSR into their corporate strategy [45].

A few years later, Greece seemed to focus on achieving sustainable development, leading its new National Growth Strategy (2018) towards the implementation of Agenda 
2030 and the 17 Sustainable Development Goals (SDGs). Provided that "no one is left behind", the first Voluntary National Report (VNR) was published at the 2018 UN HighLevel Political Forum (HLPF), as a statement on sustainable development [68].

The VNR report follows the National Growth Strategy on addressing all the SDGs, setting 8 National Priorities. These priorities cover several matters of ecology and circular economy, social inclusion and inequalities, sustainable economic growth, and governance. Since then, a National Implementation Plan for the SDGs has been pending for further integration of the SDGs, in terms of national legislation [69].

\section{Performance Implications}

\subsection{Sustainability (Environmental, Social and Governance (ESG)) Performance}

Despite the increasing level of interest in ESG and the ensuing performance of the committed firms, the focal point of business thinking has not been altruistic over time. As a matter of fact, the pursuit of profit is still the basic concern for corporations. To this aim, the corporate world has been engaged in numerous methods and practices of profit hunting. Since sustainability was considered as contributing to financial performance, organizations began to incorporate ESG practices into their core business strategy, especially after the institutionalization of reporting practices.

According to Freeman (1984) [70], the nexus of various stakeholders constitutes the direct and indirect environment of a company, classified into shareholders, internal stakeholders (employees), external stakeholders (customers, suppliers, investors) and the overall society (Cummings and Patel, 2009) [71]. Certainly, shareholder interests are not equal to all the other stakeholders. The shareholder primacy approach of Milton Friedman (1970) [72] permits shareholders to be directly involved in corporate strategy and decision-making, having a prominent role on the board of directors [73]. Proponents of CSR argue that shareholder primacy is totally incompatible with the principles of sustainable development and corporate social responsibility, setting profit maximization as the primary corporate priority. Hence, shareholder theory fails to meet all the other stakeholders' expectations, underestimating the benefits of CSR commitment as intangible [74]. Despite what the critics believe, CSR is considered to generate tangible profits for the committed companies, as discussed further below.

Provided that sustainability performance is influenced by the national institutional environment where the firm operates, a primary stakeholder may exercise more or less pressure to a firm—so as to implement CSR-leading to higher or lower sustainability performance, accordingly [75]. Similarly, Rettab et al. (2009) [76] confirm that the national institutional framework dictates the effects of CSR on organizational performance, even in emerging economies. Furthermore, Reverter et al. (2016) [77] support the positive relationship between CSR and organizational performance, introducing the mediating factor of innovation, as an enhancing agent in a fertile institutional environment. Once more, the research of Eccles at al. (2014) [78] displays national institutionalization as a benchmark for corporate social performance (CSP).

Nonetheless, Panayiotou et al. (2009) [40] claim that CSR transforms into sustainability performance only after having been a part of corporate strategy. Given that sustainability performance constitutes the realistic aspect of CSR implementation, special indices and measures have been employed [79]. In any case, ESG performance should be evaluated by qualified executives at regular intervals, for reasons of reliability. Nevertheless, reporting both on tangible and intangible assets may provide diversified information about business ESG performance. To put it in another way, disclosures consisting of accountable items are expected to show lower ESG performance than the non-accountables [42]. Although non-financial disclosures are deemed to reflect ESG performance, Font et al. (2012) [80] contest sustainability reporting as an unreliable sustainability indicator, pointing out the gap between the disclosed and actual sustainability performance, in case of "greenwashing" practices [81]. 


\subsection{Financial Performance}

Moving from shareholder priority to stakeholder value, Hsieh (2009) [82] recalls Dunfee's theory of corporate purpose as an equilibrium point. Having shown that profit is sine qua non for a corporation, this theory accepts shareholder primacy, albeit defending stakeholder rights. That is, stakeholders' requirements can be effectively fulfilled through appropriate management, without harming shareholder value.

To explore this issue further, scholars began to investigate the business case for ESG, proving that an ESG engaged company can reap financial benefits, through competitiveness [5]. Researchers all over the world ([76] for Dubai and [77] for Spain) have asserted investment in CSR can increase profitability, if stakeholders react to specific ESG activities, creating business value. Additionally, Ramanna (2013) [35] argues that CSR enhances shareholder value (although not always), if only sustainability reports internalized positive business externalities. Furthermore, Eccles et al. (2014) [18] noticed that ESG committed firms tend to perform better than the non-committed ones. However, managers must be vigilant to ESG activities as they may harm firm performance, if they surpass a given limit (Peloza and Shang, 2011) [23].

Beyond financial returns, companies tend to become more stakeholder aware, incorporating ESG into their core strategy. Research findings suggest that strategic CSR mitigates the dispute between shareholders and the other stakeholders, adding to financial performance [83-85]. Furthermore, sufficiently concentrated, and explanatory sustainability disclosures can enhance firms' profitability, since they induce legitimacy and trust to stakeholders [86,87]. In particular, investors perceive CSR actions via Earnings Response Coefficient (ERC), which is positively influenced by strategic CSR $[84,86]$.

As the field evolves, stakeholders increasingly include evidence, derived from companies' ESG commitment, into their decision-making process. As a result, more investors have been attracted to the brand new market of socially responsible investing (SRI) $[7,21,28,88-93]$. Gillan et al. (2010) [94] argue that investors, in general, are increasingly relying on non-financial data to make investments, requiring more sustainability reporting. Similarly, stock analysts do not consider CSR expenses as a loss anymore, positively evaluating the high-rated sustainable companies. On the contrary, institutional investors tend to reject the ESG committed companies, disregarding their increased operation efficiency, higher firm valuation and greater return on assets [95].

\section{Banking and Sustainability}

\subsection{Sustainability Integration}

Banks started to deal with sustainability during 1990s, increasing their interest in 2000s. Nowadays, sustainability is seen as an extra lever of economic growth by the banking sector. Practically, banks can stimulate sustainable development directing their financial policy towards sustainable companies.

Initially, social, and environmental policy used to be implemented by 'environmental management' (as the exact equivalent of 'risk management' in non-banking industries) in banks, which has been replaced by the current ESG strategy [96]. In practice, sustainability indicators and measures are proven to make environmental management systems more efficient, rewarding banks with better results (IFC, 2006).

In particular, commercial banks are the most important intermediaries between customers and investors in every national financial system, as they exchange deposits for investments [31]. Considering the degree of sustainability penetration in industry, financial services have been proven to be the exemplary expression of CSR commitment [22], as credit presupposes trust, which is the ultimate prerequisite for successful sustainability implementation [97]. As a matter of fact, banks display the most pragmatic approach concerning CSR [79].

Weber (2005) [98] introduced five models of banking sustainability integration (Eventrelated Sustainability Integration and Sustainability as New Banking Strategy, Value Driver, Public Mission and Requirement of Clients), suggesting three principles of successful inte- 
gration. Firstly, banks need to be persuaded of the added — value of sustainability to their products and services (core business of the bank). Secondly, sustainability must be reflected in banks' general strategy and not be restricted to a single domain (holistic approach). In the third place, the leading ESG-prone banks have to provide tangible information of their sustainability performance, measured by special indicators (measurable business result).

Financial institutions are the leaders in sustainability reporting, as they hold a prominent position in their customers' consciousness, displaying much more disclosures, compared to other industries [99]. Specifically, banks act as a benchmark for sustainability reporting. Indicatively, GRI is mostly utilized for estimating the ESG commitment of the banking sector.

Moreover, KPMG's (2015) [100] international survey for N100 CSR reporting companies nominated the financial service sector as the ultimate leader of GRI reporting [101]. For instance, according to a recent comparative analysis of tourism and financial sector in G8 countries [34], the total amount of non-financial disclosures published by financial institutions was fully satisfying (192 reports), compared to the tourism industry (25 reports).

It is a fact that banks are expected to be committed to ESG criteria because they are in danger of losing their reputation and customers' legitimacy, unless they disclose their non-financial information [34]. Unexpectedly, Ioannou and Serafeim (2012) found that the financial system affects sustainability performance (Annual Composite CSP index: an equally weighted average of the social and environmental score for each firm), to a smaller extent, compared to other national business systems (political, labor, education and cultural system) in a sample of 42 countries.

"In general, in emerging markets, risks are greater, but so are opportunities" (IFC, 2006). Many lines have been written in international literature about the ESG agenda of developed countries, mainly devoted to the USA and Europe [88,97], while research on sustainability integration into emerging economies is scarce. Latin America (microfinance institutions) and India (rural banks) see ESG in the light of poverty alleviation [102,103]. As regards Africa, Nigerian banks exercise ESG as an action of charity to address high socio-economic demands [104].

On the other hand, banking executives in Kenya appear to be indifferent to internal and external stakeholders' requests [105]. Conversely, Bangladesh banks seem to be committed to voluntary sustainability reporting, with stakeholders asking for more sustainability reporting [106]. Finally, Qatar banks disclose only social information, excluding environmental information from their annual reports [107].

The ensuing benefits of integrating ESG initiatives into banks' business models are indicative of their stronger reputation. The increased transparency and accountability rewards banks with long-term profitability. "Societal trust" makes them more competitive, attractive, and credible to competitors, investors, and customers [24,108].

Hence, the challenge for banks is to efficiently manage social and environmental risks, concerning strategic decisions and loans, while launching innovative products and services related to sustainability. Therefore, managers need to deal with bank's reputation and credibility enhancement, SRI, lower risk and higher returns, increased value to stakeholders, potential for business development, clients who face liability claims, non-performing loans and clients' demand, in descending order of importance [24].

\subsection{Returns on Sustainability}

Evidence from the banking sector displays a strong positive relationship between sustainability and financial performance (FP) $[18,30,78]$. Similarly, Wu and Shen (2013) reveal that CSR enhances financial performance of strategic and altruistic banks, while not affecting the 'greenwashing' ones. The latter provide a virtual sustainability engagement, in contrast with the former, which have incorporated ESG initiatives into their core business strategy. On the contrary, Soana (2011) [109] argues that there is no relevance between sustainability and financial performance in the banking sector. 
Narwal (2007) [79] observed a positive impact of CSR on Indian banks' financial performance. Carnevale et al. (2012) [36] conducted a cross-country analysis for European banks' performance and found results to be positive in Italy, Ireland, Germany, and Spain, while in Portugal, Austria and France they were negative. The latter countries provide a virtual engagement, in contrast with the former, which have incorporated ESG initiatives into their core business strategy.

Concerning the Hellenic banking sector, although it seems that there is no relationship between CSP-FP ([36,110], Eccles et al. (2014) [18] observed a strong positive relationship between sustainability and financial performance, through their empirical evidence. Five years later, Riskos et al. (2019) [110] showed that Greek banks were highly committed to sustainability issues, causing no damage to their financial profile.

\subsection{Sustainable Banking}

In the context of sustainable development, commercial banks had expanded their activities in areas like green banking, rural banking, agri-banking, ethical and social banking [31] before they reached sustainable banking. A typical example of social banking in emerging economies is microcredit/microfinance [111].

According to the International Finance Corporation (2005) survey [7], sustainable banking is a very promising business trend, which has been practiced overtime either form smaller banks (Triodos Bank, the Co-operative Bank of the UK) to larger ones (ING, UBS). However, sustainable banking is a dynamic concept, with banks passing from the traditional phase of "defensive banking (sustainability as cost generating process)", to "preventive (sustainability as regulation)" and from this stage to "offensive (sustainability as novelty)" and "sustainable banking (sustainability as vision)", in order to fully integrate sustainable development into their core strategy [96].

Bouma et al. (2001) [112] define sustainable banking as a decision, taken by banks, to only finance customers (private and corporate) whose activities do not harm the environment and society. Sustainable banking ensures that internal and external banking activities meet sustainability requirements of internal and external stakeholders, accordingly [96]. In this context, every bank is accountable to both Board of Directors, shareholders, employees and customers, suppliers, competitors, mass media, NGOs, government, local community, society, environment.

Beyond the internal drivers for sustainable growth, banks are under external pressure to integrate sustainability to their operations. As it is already mentioned, commercial banks are increasingly involved with financing economic activities adjusted to sustainable development. Provided that lending operations is the core activity of commercial banks (money supply), sustainable banking promotes lending according to an "ethical code".

Concerning corporate customers, sustainable banks tend to finance companies which are committed to sustainability principles and whose activities do not harm society and the environment in any way [98]. Hence, banks seriously consider firms' sustainability reports for mitigating the perceived risk [81]. To do so, banks screen firms' sustainability profile before providing them with loans or project financing [27]. Beyond motivation, sustainable banks can also use discouraging practices to accelerate sustainability, either imposing higher lending rates or even rejecting financing for instance.

When it comes to bank lending practices, it appears that the more the firms engage in ESG, the more financing they raise for funding investments, important for their financial viability. That happens because the firms which publish sustainability reports induce trustworthiness to their stakeholders (i.e., banks), due to the transparency of information included [113]. Furthermore, banks seem to reinforce innovation [114] and firm performance, through financing relevant activities [115].

Regarding retail clients, it is documented that if the bank sustainability strategies are customer-focused, this motivates favorable attitudes, leading to positive consumer behavior towards the bank [116]. Similarly, the study of [117] adds to the existing knowledge on the topic, supporting that bank customers respond in different ways to various ESG initiatives. 
Conversely, commercial banks, as traditional financial intermediary, equally depend on their lenders (money demand) to ensure the necessary capital adequacy, liquidity and profitability requirements [118]. In turn, the clientele evaluates the ESG commitment of the banks, in terms of liabilities.

However, the way to sustainable banking is not paved with rose petals. Contrariwise, banks face serious risks challenging their stability. First, liquidity and credit risk may hinder core banking activities. Market, interest rate and off-balance sheet risks can also jeopardize bank's proper operations. Operational insolvency and sovereign risk are also part of the long list of threats that need to be addressed [96].

Nevertheless, banks can seize many opportunities arising from their sustainability pursuits during investing and attracting investments. Sustainable banks can diversify themselves enhancing their corporate image. To put it another way, new financial (corporate payments, savings, investment and insurance products) and funding products (loans, leasing, innovation funding and securitization products), sustainable consulting services and donations can make banks very appealing to transact with [96].

As a matter of fact, banks need support in their efforts to align Paris Agreement and Agenda 2030 with their strategy. Indicatively, the UN Environment Programme (UNEP) Finance Initiative members are assisted in banking sustainability issues (climate and performance, natural capital risk and valuation, banking and human rights, positive impact, training and professional development). Under this banking program, 200 banks have signed the 6 Principles for Responsible Banking (Alignment, Impact and Target Setting, Clients and Customers, Stakeholders, Governance and Culture, Transparency and Accountability), setting a solid framework for sustainable banking. Indicatively, the signatory body accounts for the $1 / 3$ of the global banking sector, which makes up more than USD 47 trillion in global capital [119].

In Europe, ESMA (European Securities and Markets Authority) promotes a framework that supports the financial sector towards sustainable transition. The so-called 'EU Sustainable Finance Action Plan' is based on EU regulation (SDGs and Paris Climate Agreement) and ESG commitment as a driver to achieving the SDGs. The ESMA strategy provides members with special guidance and techniques to assess and manage ESG-related risks [120].

As far as Greece is concerned, the banking system has suffered a deep recession, causing serious effects to stability and performance of the Greek banking institutions. The shrinkage of the banking sector has been one of the consequences [121,122]. Despite the difficulties, the banks did endorse the ESG criteria into their strategy. In a sample of 20 systemic banks, Papastergiou and Blanas [123] demonstrated that half of the banks considered sustainability as a cost-generating process, some of them (8) confronted sustainability as a regulation (Eurobank and Alpha Bank), while only two banks thought of sustainability as a novelty (Piraeus Bank and National Bank of Greece). Apparently, none of them perceived sustainability as a vision (sustainable banking).

Ten years later, although the four Greek systemic banks successfully keep up with the principles of responsible banking, they do not seem to have become closer to the phase of sustainable banking yet. Analytically, Piraeus Bank (https:/ / www.piraeusbank.gr/en/id iwtes/unep-fi/the-6-principles-for-responsible-banking accessed on 20 April 2021) is one of the 200 banks the signed the Principles of Responsible Banking. Eurobank (https:/ /www. eurobank.gr/en/group/corporate-social-responsibility / partnerships-promoting-sustaina bility accessed on 20 April 2021) is an active member of the UN Global Compact, UNEP Finance Initiative (UNEP FI), Energy Efficiency Financial Institutions Group (EEFIG), Sustainable Development Committee of the Hellenic Bank Association (HBA), Global Sustain, is registered to Eco-Management and Audit Scheme (EMAS), while supporting the initiatives CSR Hellas and Sustainable Greece 2020 (QualityNet Foundation). Alpha Bank (https: / / www.alpha.gr / / media/alphagr / files / group / press-releases / 2019/20190 821_deltio_typou_en.pdf accessed on 20 April 2021) and National Bank of Greece (https:/ / www.nbg.gr/en/the-group/press-office/press-releases/nbg-becomes-signatory-of-the-gl 
obal-principles-for-responsible-banking accessed on 20 April 2021) S.A. are also signatories of the UNEP FI Principles of Responsible Banking.

Although B. M. R. Paiva et al. (2021) [124] are concerned about the range and complexity of sustainable banking, sustainable financial institutions can mitigate risk and outperform competitors developing innovative sustainable products, communicate sustainability integration through sustainability reporting and create initiatives participating in global networks.

\section{Results}

RQ1: How does the Institutional Environment affect corporate sustainability performance?

Addressing the first research question, the analysis is based on Campbell's (2007) [125] hypothesis arguing that national institutional environment does shape national stakeholders' attitudes towards CSR. Therefore, content analysis of many sources unanimously demonstrated that corporate sustainability performance is positively affected by sustainability reporting, as an institutional requirement. However, the performance level entirely depends on prioritization and reliability of sustainability reporting.

RQ2: Does commitment to CSR principles financially reward companies?

Similarly, content analysis has been applied to 26 different research papers for answering the second research question posed. Eventually, CSR awareness is displayed in performance gains. In detail, profit is mediated by firm value, trust, legitimacy, competitiveness, operation efficiency, ERC (earnings response coefficient), ROA (return on assets) and positive externalities internalization. Nevertheless, ESG committed companies outperform the non-committed ones even if they do not overemphasize this.

RQ3: Do banking industry returns on sustainability have a positive sign?

Proceeding to the next research question there is strong empirical evidence to support the hypothesis that ESG-prone banks can reap benefits from their investment in sustainability, disclosed in their annual sustainability reports. Specifically, almost all sources (two of the sources showed no relevance/neutral relationship) considered advocating the positive relationship between sustainability and financial performance in the banking sector. Nonetheless, bank reputation, competitiveness, attraction, credibility, transparency, and accountability intervene in that relationship, determining its outcome.

\section{Conclusions}

In retrospect, it is evident that stakeholders realized their perception was not enough for evaluating CSR commitment. Therefore, an ever-increasing demand for more information, capable of displaying companies' commitment to the principles of sustainability has arisen: sustainability reports provide stakeholders with the necessary information on ESG matters. Furthermore, eagerness for accountability and comparability led to a stream of reporting institutionalization, pressing for mandatory non-financial disclosures, especially in EU countries, including Greece. Sustainability as an integral part of core business strategy evaluated by sustainability experts cannot but enhance business ESG and financial performance.

Considering sustainability reporting as one of the sine qua non institutional requirements, this paper taken a step further: sustainability integration is assumed to affect the performance of the most ESG-committed organizations: banks. Additionally, given the cyclicity of the economy, sustainable development also fosters the interdependence of commercial banks and firms. In particular, financing an ESG committed firm or cooperating with a socially responsible bank may contribute to economic, social, or environmental enhancement of the delegator. This is a closed financial circuit in which sustainable banks can circulate sustainable money from socially responsible investors to ESG-committed companies and vice versa [96].

Thus, sustainability can trigger a feedback of financial returns. Consequently, it can be a real challenge for both managers and researchers to make a firm attractive to sustainable 
banks and vice versa, launching win-win liquidity strategies. However, sustainable banking needs to be further explored as it is quite a novel and comprehensive concept. There are various factors mediating the distance between offensive and sustainable banking to be considered in an empirical study, especially for the case of Greece.

Funding: This research received no external funding.

Institutional Review Board Statement: Not applicable.

Informed Consent Statement: Not applicable.

Data Availability Statement: No new data were created or analyzed in this study. Data sharing is not applicable to this article.

Acknowledgments: I would like to thank Charoula Kanellopoulos who proofread the text.

Conflicts of Interest: The authors declare no conflict of interest.

\section{References}

1. Brundtland, G.H. Report of the World Commission on Environment and Development: "Our Common Future"; United Nations: New York, NY, USA, 1987.

2. Carroll, A.B. A three-dimensional conceptual model of corporate performance. Acad. Manag. Rev. 1979, 4, 497-505. [CrossRef]

3. Mihelcic, J.R.; Crittenden, J.C.; Small, M.J.; Shonnard, D.R.; Hokanson, D.R.; Zhang, Q.; Schnoor, J.L. Sustainability science and engineering: The emergence of a new metadiscipline. Environ. Sci. Technol. 2003, 37, 5314-5324. [CrossRef]

4. Jenkins, H. A 'business opportunity'model of corporate social responsibility for small-and medium-sized enterprises. Bus. Ethics A Eur. Rev. 2009, 18, 21-36. [CrossRef]

5. Wu, M.W.; Shen, C.H. Corporate social responsibility in the banking industry: Motives and financial performance. J. Bank. Financ. 2013, 37, 3529-3547. [CrossRef]

6. Deegan, G. Organizational legitimacy as a motive for sustainability reporting. In Sustainability Accounting $\mathcal{E}$ Accountability; Unerman, J., Bebbington, J., O’Dwyer, B., Eds.; Routledge, Taylor and Francis Group: London, UK, 2007; ISBN 0-203-81528-9.

7. International Finance Corporation (IFC). Choices Matter: 2005 Sustainability Report; International Finance Corporation (IFC): Washington, DC, USA, 2005.

8. Yoon, Y.; Gürhan-Canli, Z.; Schwarz, N. The effect of corporate social responsibility (CSR) activities on companies with bad reputations. J. Consum. Psychol. 2006, 16, 377-390. [CrossRef]

9. Weber, O.; Scholz, R.W.; Michalik, G. Incorporating sustainability criteria into credit risk management. Bus. Strategy Environ. 2010, 19, 39-50. [CrossRef]

10. Nan, X.; Heo, K. Consumer responses to corporate social responsibility (CSR) initiatives: Examining the role of brand-cause fit in cause-related marketing. J. Advert. 2007, 36, 63-74. [CrossRef]

11. Becker-Olsen, K.L.; Cudmore, B.A.; Hill, R.P. The impact of perceived corporate social responsibility on consumer behavior. J. Bus. Res. 2006, 59, 46-53. [CrossRef]

12. Yin, C.Y.; Yu, H.Y.; Poon, P. Consumers' attributions and brand evaluations in product-harm crises: The role of implicit theories of personality. J. Consum. Behav. 2016, 15, 87-95. [CrossRef]

13. D'Souza, C.; Taghian, M.; Lamb, P. An empirical study on the influence of environmental labels on consumers. Corp. Commun. Int. J. 2006, 11, 162-173. [CrossRef]

14. Vlachos, P.A.; Tsamakos, A.; Vrechopoulos, A.P.; Avramidis, P.K. Corporate social responsibility: Attributions, loyalty, and the mediating role of trust. J. Acad. Mark. Sci. 2009, 37, 170-180. [CrossRef]

15. Marin, L.; Ruiz, S.; Rubio, A. The role of identity salience in the effects of corporate social responsibility on consumer behavior. J. Bus. Ethics 2009, 84, 65-78. [CrossRef]

16. Alvarado-Herrera, A.; Bigne, E.; Aldas-Manzano, J.; Curras-Perez, R. A scale for measuring consumer perceptions of corporate social responsibility following the sustainable development paradigm. J. Bus. Ethics 2017, 140, 243-262. [CrossRef]

17. Daub, C.H. Assessing the quality of sustainability reporting: An alternative methodological approach. J. Clean. Prod. 2007, 15, 75-85. [CrossRef]

18. Eccles, R.G.; Ioannou, I.; Serafeim, G. The impact of corporate sustainability on organizational processes and performance. Manag. Sci. 2014, 60, 2835-2857. [CrossRef]

19. Hughen, L.; Lulseged, A.; Upton, D.R. Improving stakeholder value through sustainability and integrated reporting. CPA J. 2014, $84,57$.

20. Jensen, J.C.; Berg, N. Determinants of traditional sustainability reporting versus integrated reporting. An institutionalist approach. Bus. Strategy Environ. 2012, 21, 299-316. [CrossRef]

21. Abeysekera, I. A template for integrated reporting. J. Intellect. Cap. 2013, 14, 227-245. [CrossRef]

22. Scholtens, B. Corporate social responsibility in the international banking industry. J. Bus. Ethics 2009, 86, 159-175. [CrossRef] 
23. Peloza, J.; Shang, J. How can corporate social responsibility activities create value for stakeholders? A systematic review. J. Acad. Mark. Sci. 2011, 39, 117-135. [CrossRef]

24. International Finance Corporation. Report: Banking on Sustainability: Financing Environmental and Social Opportunities in Emerging Markets; IFC, World Bank Group: Washington, DC, USA, 2007. Available online: http://www-wds.worldbank.org/servlet/WD SContentServer/IW3P/IB/2007/03/27/000020953_20070327120921/Rendered/PDF/392230IFC1Bank1tainability01PUBLIC1. pdf (accessed on 20 July 2020).

25. Greening, D.W.; Turban, D.B. Corporate social performance as a competitive advantage in attracting a quality workforce. Bus. Soc. 2000, 39, 254-280. [CrossRef]

26. Albareda, L.; Lozano, J.M.; Ysa, T. Public policies on corporate social responsibility: The role of governments in Europe. J. Bus. Ethics 2007, 74, 391-407. [CrossRef]

27. Weber, R.P. Basic Content Analysis, 2nd ed.; Sage Publications, Inc.: Thousand Oaks, CA, USA, 2008. [CrossRef]

28. Tencati, A.; Perrini, F.; Pogutz, S. New tools to foster corporate socially responsible behavior. J. Bus. Ethics 2004, 53, 173-190. [CrossRef]

29. Luo, X.; Bhattacharya, C.B. Corporate social responsibility, customer satisfaction, and market value. J. Mark. 2006, 70, 1-18. [CrossRef]

30. Simpson, W.G.; Kohers, T. The link between corporate social and financial performance: Evidence from the banking industry. $J$. Bus. Ethics 2002, 35, 97-109. [CrossRef]

31. Goyal, K.A.; Joshi, V. A study of social and ethical issues in banking industry. Int. J. Econ. Res. 2011, 2, 49-57.

32. Moravcikova, K.; Stefanikova, L'; Rypakova, M. CSR reporting as an important tool of CSR communication. Procedia Econ. Financ. 2015, 26, 332-338. [CrossRef]

33. Calabrese, A.; Costa, R.; Rosati, F. A feedback-based model for CSR assessment and materiality analysis. Account. Forum 2015, 39, 312-327. [CrossRef]

34. Akmese, H.; Cetin, H.; Akmese, K. Corporate social responsibility reporting: A comparative analysis of tourism and finance sectors of G8 countries. Procedia Econ. Financ. 2016, 39, 737-745. [CrossRef]

35. Ramanna, K. A framework for research on corporate accountability reporting. Account. Horiz. 2013, 27, 409-432. [CrossRef]

36. Carnevale, C.; Mazzuca, M.; Venturini, S. Corporate social reporting in European banks: The effects on a firm's market value. Corp. Soc. Responsib. Environ. Manag. 2012, 19, 159-177. [CrossRef]

37. Mion, G.; Loza Adaui, C.R. Mandatory nonfinancial disclosure and its consequences on the sustainability reporting quality of italian and german companies. Sustainability 2019, 11, 4612. [CrossRef]

38. Saeidi, S.P.; Sofian, S.; Saeidi, P.; Saeidi, S.P.; Saaeidi, S.A. How does corporate social responsibility contribute to firm financial performance? The mediating role of competitive advantage, reputation, and customer satisfaction. J. Bus. Res. 2015, 68, 341-350. [CrossRef]

39. Bonsón, E.; Bednárová, M. CSR reporting practices of Eurozone companies. Rev. Contab. 2015, 18, 182-193. [CrossRef]

40. Panayiotou, N.A.; Aravossis, K.G.; Moschou, P. Greece: A comparative study of CSR reports. In Global Practices of Corporate Social Responsibility; Springer: Berlin/Heidelberg, Germany, 2009; pp. 149-164.

41. Eccles, R.G.; Youmans, T. Materiality in Corporate Governance: The Statement of Significant Audiences and Materiality; Working Paper 16-023; Harvard Business School: Boston, MA, USA, 2015.

42. Grewal, J.; Serafeim, G.; Yoon, A.S. Shareholder Activism on Sustainability Issues; Harvard Business School-Faculty \& Research: Boston, MA, USA, 2016.

43. De Grosbois, D. Corporate social responsibility reporting by the global hotel industry: Commitment, initiatives and performance. Int. J. Hosp. Manag. 2012, 31, 896-905. [CrossRef]

44. Eccles, R.G.; Spiesshofer, B. Integrated Reporting for a Re-Imagined Capitalism; Working Paper 16-032; Harvard Business School: Boston, MA, USA, 2015.

45. Glavopoulos, E.; Bersimis, S.; Georgakellos, D.; Sfakianakis, M. Investigating the factors affecting companies' attitudes towards CSR and CER during the fiscal crisis in Greece. J. Environ. Plan. Manag. 2014, 57, 1612-1641. [CrossRef]

46. Kolk, A.; Pinkse, J. The integration of corporate governance in corporate social responsibility disclosures. Corp. Soc. Responsib. Environ. Manag. 2010, 17, 15-26. [CrossRef]

47. Metaxas, T.; Tsavdaridou, M. Corporate social responsibility in Europe: Denmark, Hungary and Greece. J. Contemp. Eur. Stud. 2010, 18, 25-46. [CrossRef]

48. Dharmapala, D.; Khanna, V. The Impact of Mandated Corporate Social Responsibility: Evidence from India's Companies Act of 2013. Int. Rev. Law Econ. 2018, 56, 92-104. [CrossRef]

49. Shahab, Y.; Ye, C. Corporate social responsibility disclosure and corporate governance: Empirical insights on neo-institutional framework from China. Int. J. Discl. Gov. 2018, 15, 87-103. [CrossRef]

50. Knudson, H. Road CSR. Interreg Europe. In CSR in Norway, Joint Thematic Study, NTNU (P4); European Regional Development Fund: Lille, France, 2015. Available online: https://www.interregeurope.eu/fileadmin/user_upload/tx_tevprojects/library/fil e_1523529564.pdf (accessed on 20 July 2020).

51. Peng, L.Y. CSR and the Sustainability Reporting Landscape of Malaysia. Legal Herald. 2018. Available online: https:/ www lh-ag.com/wp-content/uploads/2018/12/6-CSR-and-the-Sustainability-Reporting-Landscape-of-Malaysia.pdf (accessed on 20 August 2020). 
52. PWC. Making Your Reporting More Accessible and Effective. In Sustainability Reporting Tips; PWC: London, UK, 2014-2015. Available online: https://www.pwc.co.uk/assets/pdf/sustainability-reporting-tips-for-private-sector-organisations.pdf (accessed on 29 July 2019).

53. Ioannou, I.; Serafeim, G. The Consequences of Mandatory Corporate Sustainability Reporting: Evidence from Four Countries; Harvard Business School Research Working Paper (11-100); Harvard Business School Research: Boston, MA, USA, 2014.

54. Eur-Lex. Directive 2014/95/EU of the European Parliament and of the Council. Strasbourg, Europe. Document 3201410095. 2014. Available online: https:/ / eur-lex.europa.eu/legal-content/EN/TXT/?uri=CELEX\%3A32014L0095 (accessed on 22 October 2020).

55. Law 4403/2016. Efimeris tis Kivernisseos, 2016-07-07, Part Á, $N^{\circ}$ 125. pp. 7097-7132. Available online: https: / /www.ilo.org/dy $\mathrm{n} /$ natlex/natlex4.detail?p_isn=104602\&p_lang=en (accessed on 24 June 2018).

56. ESDN. National Implementation of 2030 Agenda for SD; ESDN: Vienna, Austria, 2020. Available online: https://www.sd-network.e $\mathrm{u} /$ ? $\mathrm{k}=$ country\%20profiles\&s=sdg\%20implementation\&country=Greece (accessed on 15 October 2020).

57. Lock, I.; Seele, P. The credibility of CSR (corporate social responsibility) reports in Europe. Evidence from a quantitative content analysis in 11 countries. J. Clean. Prod. 2016, 122, 186-200. [CrossRef]

58. UN. Sustainable Development Goals Knowledge Platform. Greece. Documents \& Reports. 2009. Available online: https://sustainabledevelopment.un.org/content/documents/dsd/dsd_aofw_ni/ni_pdfs/NationalReports/greece/NSDS_Gr eeceCSD18.pdf (accessed on 29 July 2019).

59. Skouloudis, A.; Evangelinos, K.I. Sustainability reporting in Greece: Are we there yet? Environ. Qual. Manag. 2009, 19, 43-60. [CrossRef]

60. Aravossis, K.G.; Panayiotou, N.A.; Tsousi, K. Performance analysis of the Greek corporate social responsibility reporting companies-Proposal of an evaluation methodology. Int. J. Sustain. Dev. Plan. 2008, 3, 103-116. [CrossRef]

61. EY. Sustainability Reporting Practices in Greece. A Desk Research of Published Sustainability Reports; EY: Athens, Greece, 2015; Volume 2. Available online: http://www.ey.com/Publication/vwLUAssets/EY-survey-sustainability-reporting-practices-in-greece /\$FILE/EY-survey-sustainability-reporting-practices-in-greece.pdf (accessed on 10 November 2017).

62. Belal, A.R.; Momin, M. Corporate social reporting (CSR) in emerging economies: A review and future direction. Res. Account. Emerg. Econ. 2009, 9, 119-143.

63. EY. Value of Sustainability Reporting. 2013. Available online: http://www.ey.com/Publication/vwLUAssets/EY_Value_of_sust ainability_reporting/\$FILE/EY-Value-of-Sustainability-Reporting.pdf (accessed on 10 November 2017).

64. Myrgioti, O.; Tsoulfas, G.T.; Rachaniotis, N.P. Application of the Global Reporting Initiative Sustainability Reporting Framework in Greece. Int. J. Decis. Sci. Risk Manag. 2013, 5, 180-211. [CrossRef]

65. Leonidas, P.; Mary, G.; Theofilos, P.; Amalia, T. Managers' perceptions and opinions towards corporate social responsibility (CSR) in Greece. Procedia Econ. Financ. 2012, 1, 311-320. [CrossRef]

66. Skouloudis, A.; Evangelinos, K.; Nikolaou, I. An overview of corporate social responsibility in Greece: Perceptions, developments and barriers to overcome. Bus. Ethics A Eur. Rev. 2011, 20, 205-226. [CrossRef]

67. Skouloudis, A.; Jones, N.; Malesios, C.; Evangelinos, K. Trends and determinants of corporate non-financial disclosure in Greece. J. Clean. Prod. 2014, 68, 174-188. [CrossRef]

68. UN. Sustainable Development Goals Knowledge Platform; Voluntary National Report; HLPF: Athens, Greece, 2018. Available online: https:/ / sustainabledevelopment.un.org/content/documents/19378Greece_VNR_Greece_2018_pdf_FINAL_140618.pdf (accessed on 29 July 2019).

69. HLPF. Voluntary National Review on the Implementation of the 2030 Agenda for Sustainable Development. High-Level Political Forum on Sustainable Development. Greece. 2018. Available online: https://sustainabledevelopment.un.org/content/document s/19378Greece_VNR_Greece_2018_pdf_FINAL_140618.pdf (accessed on 20 July 2019).

70. Freeman, R.E. Strategic Management: A Stakeholder Approach; Pitman: Boston, MA, USA, 1984.

71. Cummings, L.; Patel, C. Chapter 2 Stakeholder Literature Review. In Lorne Cummings, Managerial Attitudes toward a Stakeholder Prominence within a Southeast Asia Context; Patel, C., Ed.; Studies in Managerial and Financial Accounting; Emerald Group Publishing Limited: Bingley, UK, 2009; Volume 19, pp. 17-51.

72. Friedman, M. The Social Responsibility of Business Is to Increase Its Profits; Times Magazine: New York, NY, USA, 1970.

73. Olson, J.F. Professor Bebchuk's Brave New World: A Reply to "The Myth of the Shareholder Franchise". Va. L. Rev. 2007, 93, 773-787.

74. Grossman, H.A. Refining the role of the corporation: The impact of corporate social responsibility on shareholder primacy theory. Deakin L. Rev. 2005, 10, 572. [CrossRef]

75. Ioannou, I.; Serafeim, G. What drives corporate social performance? The role of nation-level institutions. J. Int. Bus. Stud. 2012, 43, 834-864. [CrossRef]

76. Rettab, B.; Brik, A.B.; Mellahi, K. A study of management perceptions of the impact of corporate social responsibility on organisational performance in emerging economies: The case of Dubai. J. Bus. Ethics 2009, 89, 371-390. [CrossRef]

77. Reverte, C.; Gómez-Melero, E.; Cegarra-Navarro, J.G. The influence of corporate social responsibility practices on organizational performance: Evidence from Eco-Responsible Spanish firms. J. Clean. Prod. 2016, 112, 2870-2884. [CrossRef]

78. Eccles, R.; Ioannou, I.; Serafeim, G. The impact of a culture of sustainability on corporate behavior and performance. Harv. Bus. Sch. Work. Pap. Ser. 2011. [CrossRef]

79. Narwal, M. CSR initiatives of Indian banking industry. Soc. Responsib. J. 2007, 3, 49-60. [CrossRef] 
80. Font, X.; Walmsley, A.; Cogotti, S.; McCombes, L.; Häusler, N. Corporate social responsibility: The disclosure-performance gap. Tour. Manag. 2012, 33, 1544-1553. [CrossRef]

81. Bebbington, J.; Unerman, J.; O’Dwyer, B. Sustainability Accounting and Accountability; Routledge: London. UK, 2014.

82. Hsieh, N.H. Corporate social responsibility and the priority of shareholders. J. Bus. Ethics 2009, 88, 553-560. [CrossRef]

83. Belu, C.; Manescu, C. Strategic corporate social responsibility and economic performance. Appl. Econ. 2013, 45, 2751-2764. [CrossRef]

84. Sayekti, Y. Strategic Corporate Social Responsibility (CSR), Company Financial Performance, and Earning Response Coefficient: Empirical Evidence on Indonesian Listed Companies. Procedia Soc. Behav. Sci. 2015, 211, 411-420. [CrossRef]

85. Foote, J.; Gaffney, N.; Evans, J.R. Corporate social responsibility: Implications for performance excellence. Total Qual. Manag. 2010, 21, 799-812. [CrossRef]

86. Dewi, D.M. The Role of CSRD on Company's Financial Performance and Earnings Response Coefficient (ERC). Procedia Soc. Behav. Sci. 2015, 211, 541-549. [CrossRef]

87. Yusoff, H.; Mohamad, S.S.; Darus, F. The influence of CSR disclosure structure on corporate financial performance: Evidence from stakeholders' perspectives. Procedia Econ. Financ. 2013, 7, 213-220. [CrossRef]

88. Buttle, M. I'm not in it for the money: Constructing and mediating ethical reconnections in UK social banking. Geoforum 2007, 38, 1076-1088. [CrossRef]

89. Becchetti, L.; Garcia, M.M. Do Collateral Theories Work in Social Banking? CEIS Research Paper; Faculty of Economics, University of Rome "Tor Vergata" Via Columbia: Rome, Italy, 2008. [CrossRef]

90. EuroSIF. European SRI Study. 2008. Available online: http://www.eurosif.org/publications/sri_studies (accessed on 10 November 2017).

91. Kaeufer, K. Socially Responsible and Green Banks as a Vehicle for Socio-Economic Development and Change; MIT: Cambridge, MA, USA, 2010.

92. Eccles, R.G.; Saltzman, D. Achieving sustainability through integrated reporting. Stanf. Soc. Innov. Rev. Summer 2011, 9, 56-61.

93. UNPRI. Principles for Responsible Investment; Finance UNEP Initiative \& United Nations Global Compact: London, UK, 2015; Available online: http:/ / www.unpri.org/about-pri/the-six-principles/ (accessed on 30 July 2018).

94. Gillan, S.; Hartzell, J.C.; Koch, A.; Starks, L. Firms' environmental, social and governance (ESG) choices, performance and managerial motivation. 2010; Unpublished Working Paper.

95. Ioannou, I.; Serafeim, G. The impact of corporate social responsibility on investment recommendations: Analysts' perceptions and shifting institutional logics. Strateg. Manag. J. 2015, 36, 1053-1081. [CrossRef]

96. Jeucken, M. Sustainable Finance and Banking: The Financial Sector and the Future of the Planet; Routledge: London, UK, 2010.

97. Peterson, R.T.; Hermans, C.M. The communication of social responsibility by US banks. Int. J. Bank Mark. 2004, 22, 199-211. [CrossRef]

98. Weber, O. Sustainability benchmarking of European banks and financial service organizations. Corp. Soc. Responsib. Environ. Manag. 2005, 12, 73-87. [CrossRef]

99. CR. 2012 Global Winners \& Reporting Trends. 2012, p. 42. Available online: http:/ / www.corporateregister.com (accessed on 31 May 2018).

100. KPMG. Currents of Change. The KPMG Survey on Corporate Responsibility Reporting. 2015. Available online: https:/ / www.kpmg.com/CN/en/IssuesAndInsights / ArticlesPublications/Documents/kpmg-survey-of-corporate-res ponsibility-reporting-2015-O-201511.pdf (accessed on 24 June 2018).

101. Global Reporting Initiative (GRI). GRI Sustainability Disclosure Database; GRI: Amsterdam, The Netherlands, 2012; Available online: http:/ / database.globalreporting.org/ (accessed on 5 September 2017).

102. International Finance Corporation (IFC). Factors Influencing Poverty Outreach among Microfinance Institutions in Latin America; IFC: Washington, DC, USA, 2017.

103. Burgess, R.; Pande, R.; Wong, G. Banking for the poor: Evidence from India. J. Eur. Econ. Assoc. 2005, 3, 268-278. [CrossRef]

104. Amaeshi, K.M.; Adi, B.C.; Ogbechie, C.; Amao, O.O. Corporate social responsibility (CSR) in Nigeria: Western mimicry of indigenous practices. In ICCSR Research Paper Series; The University of Nottingham Business School: Nottingham, UK, 2006.

105. Barako, D.G.; Brown, A.M. Corporate social reporting and board representation: Evidence from the Kenyan banking sector. J. Manag. Gov. 2008, 12, 309-324. [CrossRef]

106. Khan, H.U.Z.; Halabi, A.K.; Samy, M. Corporate social responsibility (CSR) reporting: A study of selected banking companies in Bangladesh. Soc. Responsib. J. 2009, 5, 344-357. [CrossRef]

107. AlNaimi, H.A.; Hossain, M.; Momin, M.A. Corporate social responsibility reporting in Qatar: A descriptive analysis. Soc. Responsib. J. 2012, 8, 511-526. [CrossRef]

108. Sneekes, A.; Georgakopoulos, G.; Sikalidis, A.; Rodosthenous, M. Do Bankers use managerial discretion with regard to CSR and earnings management to rebuild their reputation in the aftermath of the financial crisis? In Corporate Social Responsibility: Concepts, Methodologies, Tools, and Applications; IGI Global: Hershey, PA, USA, 2019; pp. 1103-1134.

109. Soana, M.G. The relationship between corporate social performance and corporate financial performance in the banking sector. J. Bus. Ethics 2011, 104, 133-148. [CrossRef] 
110. Riskos, K.; Dekoulou, P.; Tsourvakas, G. Contemporary Environmental CSR Strategies in the Banking Sector: The Case of Piraeus Bank. In Cases on Corporate Social Responsibility and Contemporary Issues in Organizations; IGI Global: Hershey, PA, USA, 2019; pp. 90-109.

111. Gutierrez-Nieto, B.; Serrano-Cinca, C.; Molinero, C.M. Microfinance institutions and efficiency. Omega 2007, 35, 131-142. [CrossRef]

112. Bouma, J.J.; Jeucken, M.; Kilkers, L. Sustainable Banking: The Greening of Finance; Greenleaf Publishing: Sheffield, UK, 2001.

113. Cheng, B.; Ioannou, I.; Serafeim, G. Corporate social responsibility and access to finance. Strateg. Manag. J. 2014, 35, 1-23. [CrossRef]

114. Kerr, W.R.; Nanda, R. Financing innovation. Annu. Rev. Financ. Econ. 2015, 7, 445-462. [CrossRef]

115. Lundholm, R.J.; Serafeim, G.; Yu, G. FIN around the World: The Contribution of Financing Activity to Profitability; Harvard Business School Working Paper Series\# 13-011; Harvard Business School: Boston, MA, USA, 2012.

116. McDonald, L.M.; Hung Lai, C. Impact of corporate social responsibility initiatives on Taiwanese banking customers. Int. J. Bank Mark. 2011, 29, 50-63. [CrossRef]

117. Pomering, A.; Dolnicar, S. Customers' Sensitivity to Different Measures of Corporate Social Responsibility in the Australian Banking Sector; University of Wollongong Australia: Wollongong, Australia, 2006.

118. Darus, F.; Mad, S.; Yusoff, H. The importance of ownership monitoring and firm resources on corporate social responsibility (CSR) of financial institutions. Procedia Soc. Behav. Sci. 2014, 145, 173-180. [CrossRef]

119. UNEP; FI. Banking \& Principles for Responsible Banking. 2020. Available online: https://www.unepfi.org/banking/banking/ (accessed on 20 July 2019).

120. ESMA. Strategy on Sustainable Finance; European Securities and Markets Authority (ESMA): Paris, France, 6 February 2020; Available online: https://www.esma.europa.eu/sites/default/files/library/esma22-105-1052_sustainable_finance_strategy.pdf (accessed on 6 October 2020).

121. Bank of Greece. The Chronicle of the Great Crisis; Public Interventions and Institutional Actions to Safeguard Financial Stability and Overcome the Crisis; The Bank of Greece 2008-2013; Bank of Greece: Athens, Greece, 2014; ISBN 978-960-7032-65-2. Available online: https:/ / www.bankofgreece.gr/Publications/The\%20Chronicle\%20Of\%20The\%20Great\%20Crisis.pdf (accessed on 20 April 2021).

122. Mitsakis, F.V. The impact of economic crisis in Greece: Key facts and an overview of the banking sector. Bus. Econ. Res. 2014, 4, 250-267. [CrossRef]

123. Papastergiou, A.; Blanas, G. Sustainable green banking: The case of Greece. In Proceedings of the Management of International Business and Economics Systems (MIBES) Conference, Thessaly, Greece, 17-19 September 2011; pp. $204-215$.

124. Paiva, B.M.; Ferreira, F.A.; Carayannis, E.G.; Zopounidis, C.; Ferreira, J.J.; Pereira, L.F.; Dias, P.J. Strategizing sustainability in the banking industry using fuzzy cognitive maps and system dynamics. Int. J. Sustain. Dev. World Ecol. 2021, 28, 93-108. [CrossRef]

125. Campbell, J.L. Why would corporations behave in socially responsible ways? An institutional theory of corporate social responsibility. Acad. Manag. Rev. 2007, 32, 946-947. [CrossRef] 